\title{
Does It Matter Where You Come From? Vertical Spillovers from Foreign Direct Investment and the Nationality of Investors
}

\author{
Beata Smarzynska JAVORCIK, \\ Kamal SAGGI ${ }^{\#}$ \\ and \\ Mariana SPATAREANU
}

\begin{abstract}
This study uses a firm-level panel data set from Romania to examine whether the nationality of foreign investors affects the degree of vertical spillovers from FDI. Investors' country of origin may matter for spillovers to domestic producers in upstream sectors (supplying intermediate inputs) in two ways. First, the share of intermediate inputs sourced by multinationals from a host country is likely to increase with the distance between the host and the source economy. Second, the sourcing pattern is likely to be affected by preferential trade agreements that cover some but not other source economies. In our case, the Association Agreements signed between Romania and the EU implies that inputs sourced from the EU are subject to a lower tariff than inputs sourced from the US or Asia. Moreover, while for European investors intermediate inputs sourced from home country suppliers comply with the rules of origin and thus can be exported to the EU on preferential terms, this would not be the case for home country suppliers of American or Asian multinationals. Therefore, we would expect that American and Asian investors source more from Romania than EU investors and thus present greater potential for vertical spillovers. The empirical analysis produces evidence in support of our hypothesis. We find a positive association between presence of American and Asian companies in downstream sectors and the productivity of Romanian firms in the supplying industries. Further, the productivity of Romanian firms in the supplying sectors is negatively correlated with operations of European investors in downstream sectors. The differences between the effects associated with investors of different origin are statistically significant.
\end{abstract}

Keywords: spillovers, foreign direct investment, technology transfer

JEL classification: F23

World Bank Policy Research Working Paper 3449, November 2004

The Policy Research Working Paper Series disseminates the findings of work in progress to encourage the exchange of ideas about development issues. An objective of the series is to get the findings out quickly, even if the presentations are less than fully polished. The papers carry the names of the authors and should be cited accordingly. The findings, interpretations, and conclusions expressed in this paper are entirely those of the authors. They do not necessarily represent the view of the World Bank, its Executive Directors, or the countries they represent. Policy Research Working Papers are available online at http://econ.worldbank.org.

\footnotetext{
*World Bank and CEPR, MSN MC3-303, 1818 H St, NW, Washington DC, 20433. Email: bjavorcik@worldbank.org.

\# Department of Economics, Southern Methodist University, Dallas, TX 75275-0496.Email: ksaggi@smu.edu.

- World Bank, MSN MC3-303, 1818 H St, NW, Washington DC, 20433. Email: mspatareanu@worldbank.org. The authors would like to thank Jens Arnold, Bjorn Frank, Holger Gorg, and Caglar Ozden for helpful comments and suggestions.
} 


\section{Introduction}

Many countries strive to attract foreign direct investment (FDI) by offering ever more generous incentive packages and justifying their actions with the expected knowledge externalities to be generated by foreign affiliates. Despite being hugely important to public policy, there is little conclusive evidence to support this claim, as the empirical literature searching for spillovers operating within sectors has produced mixed results. ${ }^{1}$ The picture is more optimistic in the case of inter-industry or vertical spillovers taking place through contacts between domestic firms and their multinational customers operating in the same country. Blalock and Gertler (2004), Javorcik (2004), and Javorcik and Spatareanu (2003) provide evidence consistent with the presence of positive FDI spillovers working through this channel. Little is known, however, about factors affecting such spillovers.

This is the first paper to examine factors driving the degree of vertical spillovers from FDI. Using a comprehensive data set of firms operating in Romania, this study tests whether there exists a difference in the magnitude of vertical spillovers associated with multinationals from different regions of the world (Europe, America and Asia). We believe that such difference are likely to exist for three reasons. First, as the theoretical models of vertical linkages predict, the share of intermediate inputs sourced by multinationals in a host country is positively correlated with the distance between the headquarters and the production plant in the host country (Rodrigues-Clare, 1996 and Markusen and Venables, 1999). ${ }^{2}$ And a larger share of local sourcing implies more contacts between multinationals and local firms in upstream sector and a greater potential for knowledge spillovers. ${ }^{3}$ Therefore, we would expect a higher degree of

\footnotetext{
${ }^{1}$ Most of the existing firm level studies, including Haddad and Harrison (1993) on Morocco, Aitken and Harrison (1999) on Venezuela, Djankov and Hoekman (2000) on the Czech Republic, and Konings (2001) on Bulgaria, Poland and Romania cast doubt on the existence of horizontal (i.e., intra-industry) spillovers from FDI in developing countries. They either fail to find a significant effect or produce the evidence of negative impact the presence of multinational corporations has on domestic firms in the same sector. The few studies finding evidence of positive within-sector spillovers focus on developed countries (e.g., Haskel, Pereira and Slaughter, 2002, on the UK).

${ }^{2}$ This prediction is confirmed by empirical evidence. Hanson, Mataloni and Slaughter (2003) demonstrate that sales of intermediate inputs by U.S. multinationals to their overseas affiliates decline with the trade costs. Local sourcing by Japanese investors in the United States has been reported to serve operational needs given transportation distance and potential shipping delays from Japan (Chung et al., 2003 and Martin and Swaminathan, 1995). In a recent survey of multinationals operating in the Czech Republic, when asked "Why did you choose to source inputs from a Czech supplier?" over half of the respondents mentioned the importance of proximity to suppliers and the savings on transportation costs (Javorcik and Spatareanu, 2004).

${ }^{3}$ See Pack and Saggi (2001) and Lin and Saggi (2004) for models of vertical technology transfer from multinationals to local suppliers.
} 
vertical spillovers to be associated with American and Asian investors than with European multinationals, since home countries of the former are located much farther away from Romania.

Second, preferential trade agreements, which cover some but not all investors' home countries, are likely to affect the sourcing patterns of multinationals. For example, since Romania signed the Association Agreements with the European Union (EU), its tariffs on imports from the EU and United States are sharply different. During 1999, the average tariff applied by Romania on manufacturing imports from the US and Japan was 15.78 percent whereas the corresponding tariff on imports from the EU was only 4.88 percent. ${ }^{4}$

Third, multinationals using Romania as the export platform can enjoy preferential (or even duty-free) access to EU provided a sufficient share of value in their product was added within the area covered by the agreement. This implies that while for European investors intermediate inputs purchased from home country suppliers would still comply with the rules of origin, this would not be the case for home country suppliers of American or Asian multinationals. Therefore, we expect that American and Asian investors would have a greater incentive to source locally and thus would be associated with greater knowledge spillovers to Romanian firms in the supplying sectors. ${ }^{5,6}$

Several cases studies from the automotive industry suggest that investor nationality may indeed affect the extent of local sourcing. For instance, UNCTAD (2001, p. 166) reports that in the case of Suzuki's investment in Hungary rules of origin under the Association Agreement with the EU were a factor in the firm's decision to locate there, create local linkages and increase local value added, so as to enjoy duty-free access for car exports to EU markets. Similarly, Daewoo, which invested in Romania, stated that it intended to reach a 60 percent localization level of the production. In 1997, 16.9 percent of the components of Daewoo's Cielo

\footnotetext{
${ }^{4}$ Source: WITS database. The figures in the text refer to simple averages which were calculated based on the tariff data for 8- (for EU) or 6-digit (for US and Asia) HS categories. Manufacturing sectors are defined as HS 25-97.

${ }^{5}$ Of course, this will not be true of all American or Asian investors as many of them may still choose to import their inputs from countries covered by the Agreement. Nevertheless, we would expect to observe a broad trend following this pattern. Similarly, a certain number of European investors are likely to engage in local sourcing. Overall, however, we would expect that importing intermediate inputs would be more advantageous to European than to other multinationals as European multinationals can combine sourcing for their headquarters, Romanian plants and possibly sister companies in Europe in order to enjoy volume discounts. It has been pointed out that centralized or pooled group-sourcing arrangements may encourage affiliates to use foreign sources even when local suppliers are available (see UNCTC 2001, p. 136).

${ }^{6}$ Note that preferential trade agreements may also alter the incentives for investment. Lured by low wages and guaranteed access to European Union market, foreign investment in the auto industry in Central European countries has soared in recent years. For example, the South Korean Hyundai group is expected to build a $\$ 850 \mathrm{~m}$ Kia plant in Slovakia (The Economist, March 6th-12th 2004).
} 
model were produced in Romania, and these 300 Romanian components were supplied by 43 Romanian companies. In the same year, about 40 percent of Cielos produced in Romania were exported, mainly to other Eastern European countries which signed the Association Agreements with the EU. On the other hand, when the French multinational, Renault, purchased an equity stake in Dacia, the Romanian car maker, in 1999, it promised to continue sourcing inputs from local suppliers provided they lived up to its expectations. This, however, does not seem to have been the case. In 2002, eleven foreign suppliers of the French group were expected to start operating in Romania, thus replacing the Romanian producers from whom Dacia used to source (Ziarul Financiar (Financial Newspaper) April 19, 2001).

The low propensity of European investors to source intermediate inputs from Romania may actually hurt domestic firms in upstream sectors. The entry of foreign investors is likely to increase the level of competition in downstream industries driving weaker firms out of business. As they exit, part of their market share may be acquired by European multinationals, resulting in lower demand for domestically produced intermediate inputs. Moreover, European investors entering Romania through acquisitions of local firms are likely to sever existing linkages to local suppliers again lowering the demand for domestically produced intermediates. A drop in demand for intermediates, on the other hand, will force producers in the supplying sectors to spread their fixed cost over a smaller market share and thus will lower their productivity.

Our hypothesis is tested using data from the Amadeus database which includes information on 50,597 firms operating in Romania. Over 11 percent of these firms are foreign owned with 4,856 firms being affiliates of European companies, 434 of American and 406 of Asian corporations. We estimate a production function controlling for the share of output in a given industry coming from foreign owned entities (a proxy for intra-industry spillovers from FDI) and for the foreign presence in downstream sectors (potential buyers of intermediate inputs). The latter measure is calculated separately for European, American and Asian owned companies.

Our results can be summarized as follows. We find a statistically significant and positive association between the presence of American and Asian companies in downstream sectors and the productivity of Romanian firms in the supplying industries. At the same time, the productivity of Romanian firms in the supplying sectors is negatively correlated with operations of European investors in downstream industries. The differences between the effects stemming 
from investors of different origin are statistically significant. The findings are robust to controlling for firm-specific fixed effects. Moreover, the results do not change after we implement the Olley and Pakes (1996) correction for endogeneity of input selection.

We conclude that the observed pattern is consistent with our hypothesis that FDI inflows from far away source countries which are not part of the preferential trade agreement are more likely to be associated with local sourcing and thus vertical productivity spillovers taking place through contacts with local suppliers of intermediate inputs.

This paper is structured as follows. In the next section, we discuss FDI inflows into Romania. Then we present our data, estimation strategy and the empirical results. The last section concludes.

\section{FDI in Romania}

Compared to Central and Eastern European countries Romania was a late bloomer as an FDI destination in the region. The Romanian government's cautious approach to privatization and to transition in general had led to relatively slow FDI inflows during the early 1990s. The situation changed dramatically in 1997 when substantial privatization efforts along with changes in the legislative framework provided new opportunities for foreign investors. As a result, the volume of FDI inflows in 1997 and 1998 was thirteen and twenty-one times larger, respectively, than the amount received in 1993 (see Table 1). In the following two years a slowdown was registered as FDI inflows as a percentage of GDP decreased from 4.9 percent in 1998 to 3.0 percent in 1999 and 2.8 percent in 2000 . Nevertheless, the total FDI stock accumulated between 1993 and 2000, equal to 6,429 million dollars, made Romania the fourth largest FDI recipient among ten countries in the region.

According to the UNCTAD's Inward FDI performance index, Romania success in attracting FDI was also particularly visible in 1997 and 1998. The index is computed as the ratio of a country's share in global FDI flows to its share in the global GDP. Countries with an index value of one are FDI recipients in line with their relative GDP, while those with an index above one attract more FDI than what would be expected given their economic size. In 1996 the index value for Romania was 0.58 increasing to above 2 in $1997-98$ and then declining to 0.82 and 0.59 in the two following years (UNCTAD, 2001). 
At the end of 2000, there were 77,241 companies with foreign capital in Romania, which represented about 9 percent of all companies registered in the country. ${ }^{7}$

Foreign companies played an important role in the Romanian economy accounting for two-fifths of sales and exports. FDI is mainly concentrated in labor intensive industries and have been primarily export-driven (Dumitriu and Hunya, 2002, Voinea, 2002). About 45 percent of FDI stock in 2000 was concentrated in manufacturing industries, with the rest found mainly in trade and financial services (Hunya, 2002).

In terms of the distribution of FDI by the source country, at the end of 200061 percent of the FDI stock was accounted for by investors from the European Union, 10 percent by the Asian capital and 8 percent by American investors (Hunya, 2002). The largest source countries included the Netherlands, France, Italy, Germany, the United States, the United Kingdom and Greece. $^{8}$

\section{Data Description}

The data used in this study come from a commercial database Amadeus compiled by Bureau van Dijk, which contains comprehensive information on companies operating in 35 European countries, including Romania. The Amadeus database covers 387,357 out of 783,969 (308,064 reported active) firms registered in Romania at the end of year $2000 .^{9}$ The difference comes from the fact that while Amadeus includes some inactive companies, it does not cover state owned firms or co-operatives. Information on the firms included in Amadeus comes from the Chamber of Commerce and Industry of Romania.

In addition to the standard financial statements, Amadeus includes detailed information about the ownership structure of firms which allows us to determine the amount and the country of origin of the foreign equity stake in each company. While having information on the foreign equity share is not difficult to find, knowing the source country of the foreign capital is a unique feature of our data set. The database contains only the latest available ownership information

\footnotetext{
${ }^{7}$ http://www.factbook.ro/countryreports/ro/Ro_InvestmentClimate.htm

${ }^{8}$ Ibid.

${ }^{9}$ Source: Romanian Statistical Yearbook (2001).
} 
(mostly for 2000 and 1999) and no historical figures. ${ }^{10}$ For this reason, we limit our analysis to an unbalanced panel spanning the period 1998-2000. We assume that firms which were foreignowned in the year for which we have the ownership information were foreign-owned during the whole three-year period.

The sample includes firms with more than five employees in 1999. After deleting inactive firms and missing observations and removing outliers, ${ }^{11}$ we are left with 50,597 firms (or 131,396 firm-year observations, between 42,246 and 50,597 observations per year). For 5,696 firms the foreign capital share exceeds 10 percent of the total.

We also employ the input-output matrix provided by the Statistical Institute of Romania for the first year covered by the sample 1998. ${ }^{12}$ The input-output matrix covers 105 sectors and each firm in our dataset is matched with the IO sector classification based on its primary threedigit NACE code. ${ }^{13}$ Both manufacturing and service sectors (87 in total) are represented in our sample. A detailed sectoral distribution of firms is presented in Table 2. As summary statistics presented in Table 3 indicate, a large degree of heterogeneity is found in the case of outputs, inputs and ownership type.

\section{Empirical Strategy}

\section{Model and Estimation Issues}

To examine the effect of foreign presence on the productivity of domestic firms, we estimate a log-linear transformation of a Cobb-Douglas production function:

$$
\begin{aligned}
\ln \mathrm{VA}_{\mathrm{it}}=\ln \mathrm{Y}_{\mathrm{it}}-\operatorname{lnM}_{\mathrm{it}}= & \alpha_{\mathrm{i}}+\beta_{1} \operatorname{lnK}_{\mathrm{it}}+\beta_{2} \operatorname{lnL} \mathrm{it}_{\mathrm{it}}+\beta_{3} \text { Vertical_European }_{\mathrm{jt}}+\beta_{4} \text { Vertical_American }_{\mathrm{jt}}+ \\
& \beta_{5} \text { Vertical_Asian }_{\mathrm{jt}}+\beta_{6} \text { Horizontal }_{\mathrm{jt}}+\alpha_{\mathrm{t}}+\varepsilon_{\mathrm{ijt}}
\end{aligned}
$$

\footnotetext{
${ }^{10}$ Despite this shortcoming many researchers studying European economies have employed the Amadeus data. See, for instance, Budd, Konings and Slaughter (2002), Castellani and Zanfei (2001), Konings and Murphy (2001), Konings, Rizov and Vandenbussche (2003), Schoors and van der Tol (2001).

${ }^{11}$ Firms in the top and bottom one percentile of all the firm-specific output and input variables were deleted from the sample.

12 Ideally we would like to use multiple input-output matrices since relationships between sectors may change over the years or with FDI inflows, albeit radical changes are unlikely. Unfortunately, input-output matrices for later years are not available.

${ }^{13}$ For the concordances between the IO industry codes and three digits NACE codes see Javorcik and Spatareanu (2003).
} 
where subscripts $i, j$ and $t$ refer to firm, industry and time, respectively. $\mathrm{VA}_{\mathrm{it}}$ stands for firm's value added, $\mathrm{Y}_{\mathrm{it}}$ output, $\mathrm{M}_{\mathrm{it}}, \mathrm{K}_{\mathrm{it}}, \mathrm{L}_{\mathrm{it}}$ and represent production inputs: materials, capital and labor. $\alpha_{i}$ and $\alpha_{t}$ capture firm and time fixed effects, respectively. Firm fixed effects control for unobserved firm characteristics, such a managerial talent, availability of better infrastructure or access to financing, etc., which may affect firm productivity. We define firm's output as turnover deflated by industry specific producer price indices at the two-digit NACE classification. Material inputs are deflated by a weighted average of the producer price indices of the supplying sectors. The weights are given by the input-output matrix and represent the proportion of inputs sourced from a given sector. We measure labor by the number of employees. Capital is proxied by the value of tangible fixed assets deflated using the GDP deflator.

In addition to the standard production function variables, we include measures of foreign presence in the same sector (Horizontal) as well as in downstream sectors (Vertical), which are defined as follows. Horizontal ${ }_{\mathrm{jt}}$ is the share of an industry $\mathrm{j}$ 's output produced by firms with at least 10 percent foreign equity, calculated for each of the 87 industries. Even though the number of foreign firms does not change during the sample period, output fluctuates and thus it is a sector-specific time-varying variable.

The variable Vertical $_{\mathrm{jt}}$ is a proxy for the foreign presence in downstream sectors (i.e., sectors supplied by the industry to which the firm in question belongs) and thus is intended to capture the effect multinational customers from a particular region of origin have on domestic suppliers. It is defined in the following way:

$$
\text { Vertical_Origin }_{\mathrm{jt}}=\Sigma_{\mathrm{k}} \alpha_{\mathrm{jk}} \text { Horizontal_Origin }_{\mathrm{kt}}
$$

where $\alpha_{j k}$ is the proportion of sector j's output used by sector k taken from the input-output matrix. ${ }^{14}$ We calculate three separate measures of Vertical for three regions of origin of foreign investors: Europe, America and Asia. In order to do so, each foreign affiliate is assigned to one of the three regions in following manner. Europe encompasses investors from all European countries (EU members, accession countries and non-members) as well as Turkey. ${ }^{15}$ America includes both North and South America, but the grouping consists primarily of the U.S. and Canadian investors. Among Asian investors China, Lebanon, Syria, Iraq have the higher number

\footnotetext{
${ }^{14}$ In calculating $\alpha_{j k}$ sector $j$ 's output sold for final consumption was excluded.

${ }^{15}$ We have 342 Turkish investors in the sample. Turkey has been classified as a European country because of its proximity and the fact that since 1995 it has formed a Customs Union with the EU.
} 
of projects but in terms of volume the Republic of Korea is the dominant source country. Firms with shareholders of multiple origins were dropped from the sample. ${ }^{16}$

Table 1A in the Appendix presents the distribution of foreign affiliates in the three groups across sectors. Note that it is quite similar across the three groups of investors. The regional distribution of the multinationals follow similar patterns for the American and Asian as well as the European investors. The summary statistics of all variables are listed in Table 2. The model specified in equation (1) is estimated on the sample of purely Romanian firms, since we are primarily interested in the impact of foreign presence on domestic producers.

We restrict our attention to domestic establishments to avoid a potential bias stemming from the fact that foreign investors tend to acquire stakes in large and most successful domestic companies (see Djankov and Hoekman, 2000). We use firm fixed effects estimation in order to take into account the unobserved firm characteristics, such a managerial talent, access to financing, etc., which may affect firm productivity. Doing so will allow us to control for time invariant determinants of productivity across firms that are also potentially correlated with FDI variables.

Further, we control for the fact that firm's private knowledge of its productivity (unobserved by the econometrician) may affect the input decisions, leading to biased estimates of the coefficients on factor shares, and employ the semi-parametric approach to estimating production function parameters suggested by Olley and Pakes (1996) and modified by Levinsohn and Petrin (2003). ${ }^{17}$ This method allows for firm-specific productivity differences that exhibit idiosyncratic changes over time and thus addresses the simultaneity bias. Since our study relies on correctly measuring firm productivity, obtaining consistent estimates of the production function coefficients is crucial to our analysis.

\section{$\underline{\text { Results }}$}

First, we present the results from the fixed effect model (without the Olley-Pakes correction), which, as evident from Table 3, lend support to our hypothesis. As anticipated, we find that the productivity of domestic firms is positively correlated with the presence of

\footnotetext{
16 There were 1,335 such firm-year observations.

${ }^{17}$ See Appendix for a detailed description of the method.
} 
American and Asian investors in downstream sectors (potential buyers of intermediate inputs). Further, consistent with our expectations, the data indicate that operations of European firm in sectors purchasing intermediates is negative correlated with the productivity of Romania firms in the supplying industries. All of these effects are statistically significant at the one percent level, both when entered individually or together into the estimated equation. The differences between the effects associated with European and Asian as well as European and American investors are statistically significant at the one percent level. Finally, we find evidence of positive spillovers working within industries.

Next we correct for the endogeneity of input selection by applying the Olley-Pakes procedure to estimate the total factor productivity (TFP) for each sector separately, and then use the TFP estimates as the dependent variable in the regression including spillover proxies. The results, shown in the first two columns of Table 4, are consistent with those obtained from the fixed effect model. Again all measures of vertical spillovers bear the expected signs and are statistically significant at the one percent level.

Finally, we correct the standard errors to take into account the fact that the measures of potential spillovers are industry specific while the observations in the data set are at the firm level. As Moulton (1990) pointed out, failing to make such a correction may lead to a downward bias in the estimated errors, thus resulting in a spurious finding of statistical significance for the aggregate variable of interest. We perform the correction by clustering the standard errors for firms operating in the same industry in the same year. The results with this modification are presented in the last two columns of Table 4. As expected, the correction inflated standard errors on spillover variables, and caused the coefficients on Vertical_Asian and Horizontal to lose their significance. However, the coefficients on vertical spillover proxies associated with American and European FDI remained statistically significant. Moreover, the difference between the magnitudes of the two effects remained statistically significant as well.

\section{Conclusions}

This study uses a firm-level panel data set from Romania to examine whether nationality of foreign investors affects the degree of vertical spillovers from FDI. Foreign investors' country of origin may matter for spillovers to domestic producers in upstream sectors (supplying intermediate inputs) in two ways. First, the share of intermediate inputs sourced by 
multinationals from a host country is likely to increase with the distance between the host and the source economy. In turn, a larger share of local sourcing implies more contacts between multinationals and local firms in upstream sectors and thus a greater potential for knowledge spillovers. Second, preferential trade agreements of which some but not other investors are members are also likely to affect the sourcing patterns of foreign affiliates. In our case, the Association Agreements signed between Romania and the EU implies that while for European investors intermediate inputs sourced from home country suppliers comply with the rules of origin and thus can be exported to the EU on preferential terms, this would not be the case for home country suppliers of American or Asian multinationals.

Given these two effects, we expect that American and Asian investors have a greater incentive to source locally than European multinationals and thus are likely to be associated with greater knowledge spillovers to Romanian firms in the supplying sectors. We also anticipate that the low propensity of European investors to source from Romania may hurt domestic firms in upstream sectors. Entry of foreign investors is likely to increase the level of competition in downstream industries driving weaker firms out of business and shifting part of their market share to European multinationals, which results in lower demand for domestically produced intermediates. Moreover, European investors entering Romania through acquisitions of local firms are likely to sever existing linkages to local suppliers again lowering the demand for domestically produced intermediates. This drop in demand for intermediates will force producers in the supplying sectors to spread their fixed cost over a smaller market share and thus will lower their productivity.

Our empirical analysis produces evidence in support of the above hypothesis. We find a statistically significant and positive association between the presence of American and Asian companies in downstream sectors and the productivity of Romanian firms in the supplying industries. The data also indicate that operations of European investors in downstream sectors are negatively correlated with the productivity of Romanian firms in the supplying industries. The differences between the effects stemming from investors of different origin are statistically significant. We conclude that the observed pattern is consistent with our hypothesis that FDI inflows from far away source countries that are not part of the preferential trade agreement are more likely to be associated with positive vertical spillovers. Thus in sum, nationality of foreign investors does seem to matter for FDI spillovers. 


\section{Bibliography}

Aitken, Brian J. and Ann E. Harrison. 1999. "Do Domestic Firms Benefit from Direct Foreign Investment? Evidence from Venezuela," American Economic Review. 89(3): 605-618

Budd, John, Josef Konings and Matthew J. Slaughter. 2002. "International Rent Sharing in Multinational Firms,” NBER Working Paper No. 8809.

Blalock, Garrick and Paul Gertler. 2004. "Welfare Gains from Foreign Direct Investment through Technology Transfer to Local Suppliers," unpublished manuscript, Cornell University.

Castellani, Davide and Antonello Zanfei, 2001. "Productivity Gaps, Inward Investments and Productivity of European Firms" 0107001, Economics Working Paper Archive at WUSTL.

CEEMAN. 1997. "Daewoo Automobile Romania Teaching Note." www.ceeman.org/activities/case991.html.

Chung, Wilbur, William Mitchell and Bernard Yeung. 2003. "Foreign Direct Investment and Host Country Productivity: The American Automotive Component Industry in the 1980s," Journal of International Business Studies, 34: 199-218.

Dumitriu, Irina and Gabor Hunya. 2002. "Economic Restructuring thorough FDI in Romania," mimeo, Vienna Institute for International Studies.

Haddad, Mona and Ann Harrison. 1993. "Are There Positive Spillovers from Direct Foreign Investment" Evidence from Panel Data for Morocco." Journal of Development Economics. 42(1): 51-74.

Hallward-Driemeier, Mary, Giuseppe Iarossi and Kenneth L. Sokoloff. 2002. "Exports and Manufacturing Productivity in East Asia: A Comparative Analysis with Firm-Level Data," NBER Working Paper No 8894.

Hanson, Gordon. Raymond Mataloni and Matthew Slaughter.2003. "Vertical Production Networks." NBER Working Paper 9723.

Haskel, Jonathan E., Sonia C. Pereira and Matthew J. Slaughter. 2002. "Does Inward Foreign Direct Investment Boost the Productivity of Domestic Firms?" NBER Working Paper 8724.

Javorcik, Beata Smarzynska. 2004. "Does Foreign Direct Investment Increase the Productivity of Domestic Firms? In Search of Spillovers through Backward Linkages," American Economic Review, 94(3): 605-27.

Javorcik, Beata Smarzynska and Mariana Spatareanu. 2003. "To Share or Not To Share: Does Local Participation Matter for Spillovers from Foreign Direct Investment?,” World Bank Policy Research Working Paper No. 3118.

Javorcik, Beata Smarzynska and Mariana Spatareanu. 2004. "Disentangling FDI Spillover Effects: What Do Firm Perceptions Tell Us?” in Magnus Blomstrom, Edward Graham and Theodore Moran, eds., The Impact of Foreign Direct Investment on Development: New Measures, New Outcomes, New Policy Approaches, Institute for International Economics, Washington, DC, forthcoming. 
Konings, Jozef. "The Effects of Foreign Direct Investment on Domestic Firms," Economics of Transition, 2001, 9(3), pp. 619- 633.

Konings, Jozef and A. Murphy. 2001. "Do Multinational Enterprises Substitute Parent Jobs for Foreign Ones? Evidence from European Firm-Level Panel Data", CEPR Discussion Paper 2972

Konings, Jozef, , Marian Rizov and Hylke Vandenbussche, 2003. "Investment and Financial Constraints in Transition Economies: Micro Evidence from Poland, the Czech Republic, Bulgaria and Romania”, Economics Letters, Volume 78, Issue 2, February 2003, Pages 253-258

Levinsohn, James and Amil Petrin. 2003. "Estimating Production Functions Using Inputs to Control for Unobservables," Review of Economic Studies 70(2): 317-41.

Lin, Ping and Kamal Saggi. 2004. "Multinational Firms and Backward Linkages: A Critical Survey and a Simple Model," in Magnus Blomstrom, Edward Graham, and Theodore Moran, eds., The Impact of Foreign Direct Investment on Development: New Measures, New Outcomes, New Policy Approaches, Institute for International Economics, Washington DC, forthcoming.

Markusen, James R. and Venables, Anthony J. 1999. "Foreign Direct Investment as a Catalyst for Industrial Development." European Economic Review 43(2): 335-356.

Martin, Xavier, Will Mitchell and Anand Swaminathan. 1995. "Recreating and Extending Japanese Automobile Buyer-supplier Links in North America," Strategic Management Journal. 16: 580-619.

Moulton, Brent R. 1990. "An Illustration of a Pitfall in Estimating the Effects of Aggregate Variables on Micro Units." Review of Economics and Statistics 72(2):334-338.

Olley, Steven G. and Ariel Pakes. 1996. "The Dynamics of Productivity in the Telecommunications Equipment Industry," Econometrica 64(6), pp. 1263-1297.

Pack, Howard and Kamal Saggi. 2001. "Vertical Technology Transfer via International Outsourcing." Journal of Development Economics 65, 389-415.

Rodriguez-Clare, Andres. 1996. "Multinationals, linkages, and economic development," American Economic Review 85, pp. 852-73.

Voinea, Liviu. 2002. "Revisiting FDI Patterns in Transition: The Case of Romania," mimeo Romanian American University, Bucharest.

UNCTAD. 2001. World Investment Report. Promoting Linkages. 
Table 1. FDI Inflows into CEEC-10 1993-2000

\begin{tabular}{l|rrrrrrrrrr}
\hline & \multicolumn{7}{|c}{ FDI inflow (millions of US\$) } \\
\hline Poland & 1993 & 1994 & 1995 & 1996 & 1997 & 1998 & 1999 & 2000 & $1993-2000$ \\
\hline Czech Republic & 1,715 & 1,875 & 3,659 & 4,498 & 4,908 & 6,365 & 7,270 & 9,342 & 39,632 \\
Hungary & 654 & 878 & 2,568 & 1,435 & 1,286 & 3,700 & 6,313 & 4,583 & 21,417 \\
Romania & 2,350 & 1,144 & 4,519 & 2,274 & 2,167 & 2,037 & 1,977 & 1,692 & 18,159 \\
Slovak Republic & $\mathbf{9 4}$ & $\mathbf{3 4 1}$ & $\mathbf{4 1 9}$ & $\mathbf{2 6 3}$ & $\mathbf{1 , 2 1 5}$ & $\mathbf{2 , 0 3 1}$ & $\mathbf{1 , 0 4 1}$ & $\mathbf{1 , 0 2 5}$ & $\mathbf{6 , 4 2 9}$ \\
Bulgaria & 199 & 270 & 236 & 351 & 174 & 562 & 354 & 2,052 & 4,198 \\
Latvia & 40 & 105 & 90 & 109 & 505 & 537 & 806 & 1,002 & 3,194 \\
Lithuania & 45 & 214 & 180 & 382 & 521 & 357 & 348 & 407 & 2,454 \\
Estonia & 30 & 31 & 73 & 152 & 355 & 926 & 486 & 379 & 2,432 \\
Slovenia & 162 & 214 & 201 & 150 & 266 & 581 & 305 & 387 & 2,268 \\
\hline
\end{tabular}

Source: IMF International Financial Statistics (FDI figures) 
Table 2. Summary Statistics

\begin{tabular}{|c|c|c|c|c|}
\hline & Variable & Obs & Mean & Std. Dev. \\
\hline \multirow[t]{5}{*}{ Domestic firms } & Turnover (th. Lei 1995) & 117,039 & $6,671.4$ & $11,187.2$ \\
\hline & Value Added (th. Lei 1995) & 117,039 & $2,131.2$ & $5,073.2$ \\
\hline & Fixed Assets (th. Lei 1995) & 117,039 & $1,399.7$ & $3,750.6$ \\
\hline & Materials (th. Lei 1995) & 117,039 & $4,132.0$ & $7,328.8$ \\
\hline & Labor & 117,039 & 20.9 & 38.2 \\
\hline \multirow[t]{5}{*}{ European affiliates } & Turnover (th. Lei 1995) & 11,962 & $13,680.0$ & $18,503.1$ \\
\hline & Value Added (th. Lei 1995) & 11,962 & $6,474.7$ & $11,023.5$ \\
\hline & Fixed Assets (th. Lei 1995) & 11,962 & $3,010.8$ & $5,714.3$ \\
\hline & Materials (th. Lei 1995) & 11,962 & $6,492.7$ & $10,478.2$ \\
\hline & Labor & 11,962 & 31.8 & 51.8 \\
\hline \multirow[t]{5}{*}{ American affiliates } & Turnover (th. Lei 1995) & 1,059 & $14,513.9$ & $18,233.1$ \\
\hline & Value Added (th. Lei 1995) & 1,059 & $6,812.7$ & $11,592.6$ \\
\hline & Fixed Assets (th. Lei 1995) & 1,059 & $3,299.2$ & $5,992.0$ \\
\hline & Materials (th. Lei 1995) & 1,059 & $6,996.0$ & $10,626.1$ \\
\hline & Labor & 1,059 & 27.1 & 41.4 \\
\hline \multirow[t]{5}{*}{ Asian affiliates } & Turnover (th. Lei 1995) & 887 & $12,661.8$ & $17,750.7$ \\
\hline & Value Added (th. Lei 1995) & 887 & $3,702.8$ & $7,674.0$ \\
\hline & Fixed Assets (th. Lei 1995) & 887 & $2,070.9$ & $4,415.9$ \\
\hline & Materials (th. Lei 1995) & 887 & $8,117.1$ & $11,974.2$ \\
\hline & Labor & 887 & 19.5 & 33.8 \\
\hline \multirow[t]{4}{*}{ Spillover variables } & Horizontal & 132,282 & 0.170 & 0.080 \\
\hline & Vertical European & 132,282 & 0.090 & 0.050 \\
\hline & Vertical American & 132,282 & 0.006 & 0.005 \\
\hline & Vertical Asian & 132,282 & 0.005 & 0.003 \\
\hline \multirow[t]{5}{*}{ Spillover variables } & & No. of sectors & Mean & Std. Dev. \\
\hline & Horizontal & 87 & 0.216 & 0.130 \\
\hline & Vertical European & 87 & 0.129 & 0.085 \\
\hline & Vertical American & 87 & 0.009 & 0.006 \\
\hline & Vertical Asian & 87 & 0.005 & 0.004 \\
\hline
\end{tabular}


Table 3. Results from Regressions with Firm Fixed Effects

\begin{tabular}{|c|c|c|c|c|c|}
\hline Fixed Assets & $\begin{array}{r}0.136^{\star * *} \\
(0.003)\end{array}$ & $\begin{array}{r}0.137^{\star * *} \\
(0.003)\end{array}$ & $\begin{array}{r}0.137^{\star \star \star} \\
(0.003)\end{array}$ & $\begin{array}{r}0.137^{\star \star \star} \\
(0.003)\end{array}$ & $\begin{array}{r}0.136^{\star * *} \\
(0.003)\end{array}$ \\
\hline Labor & $\begin{array}{c}0.629 * * * \\
(0.007\end{array}$ & $\begin{array}{r}0.629^{* * *} \\
(0.007)\end{array}$ & $\begin{array}{c}0.631^{\star * *} \\
(0.007)\end{array}$ & $\begin{array}{r}0.629^{* * *} \\
(0.007)\end{array}$ & $\begin{array}{r}0.630^{* * *} \\
(0.007)\end{array}$ \\
\hline Vertical European & $\begin{array}{r}-0.925^{\star * *} \\
(0.181)\end{array}$ & & & $\begin{array}{r}-1.349^{* * *} \\
(0.187)\end{array}$ & $\begin{array}{r}-1.169^{* * *} \\
(0.190)\end{array}$ \\
\hline Vertical American & & $\begin{array}{c}9.218^{* * *} \\
(1.158)\end{array}$ & & $\begin{array}{r}10.581^{* * *} \\
(1.207)\end{array}$ & $\begin{array}{r}9.968^{* * *} \\
(1.212)\end{array}$ \\
\hline Vertical Asian & & & $\begin{array}{r}15.878^{* * *} \\
(1.914)\end{array}$ & $\begin{array}{r}13.959^{\star * *} \\
(1.924)\end{array}$ & $\begin{array}{r}15.109^{* \star *} \\
(1.936)\end{array}$ \\
\hline Horizontal & & & & & $\begin{array}{r}0.517^{* * *} \\
(0.096)\end{array}$ \\
\hline Intercept & $\begin{array}{r}4.260^{\star * *} \\
(0.028)\end{array}$ & $\begin{array}{c}4.117^{\star * *} \\
(0.023)\end{array}$ & $\begin{array}{c}4.108^{\star * *} \\
(0.024)\end{array}$ & $\begin{array}{c}4.176^{\star * *} \\
(0.029)\end{array}$ & $\begin{array}{r}4.069^{\star * *} \\
(0.035)\end{array}$ \\
\hline No. of obs. & 117,039 & 117,039 & 117,039 & 117,039 & 117,039 \\
\hline Adjusted R-squared & 0.36 & 0.36 & 0.36 & 0.35 & 0.35 \\
\hline Year fixed effects & yes & yes & yes & yes & yes \\
\hline \multicolumn{6}{|c|}{ test $V$ European $=V$ American } \\
\hline F stat & & & & 88.42 & 76.05 \\
\hline prob $>F$ stat & & & & 0.00 & 0.00 \\
\hline \multicolumn{6}{|c|}{ test V European $=\mathrm{V}$ Asian } \\
\hline F stat & & & & 63.11 & 70.77 \\
\hline prob>F stat & & & & 0.00 & 0.00 \\
\hline \multicolumn{6}{|c|}{ test V Asian = V American } \\
\hline F test & & & & 2.01 & 4.57 \\
\hline prob>F stat & & & & 0.16 & 0.03 \\
\hline
\end{tabular}


Table 4. Results from Regressions with Olley-Pakes Correction

\begin{tabular}{|c|c|c|c|c|}
\hline Vertical European & $\begin{array}{r}-1.801^{* * *} \\
(0.315)\end{array}$ & $\begin{array}{r}-1.687^{* * *} \\
(0.321)\end{array}$ & $\begin{array}{r}-1.801^{* *} \\
(0.854)\end{array}$ & $\begin{array}{r}-1.687^{* *} \\
(0.805)\end{array}$ \\
\hline Vertical American & $\begin{array}{c}6.771^{* \star *} \\
(2.144)\end{array}$ & $\begin{array}{r}6.409 * * * \\
(2.153)\end{array}$ & $\begin{array}{l}6.771^{*} \\
(3.873)\end{array}$ & $\begin{array}{l}\text { 6.409* } \\
(3.846)\end{array}$ \\
\hline Vertical Asian & $\begin{array}{c}9.108^{* * *} \\
(3.297)\end{array}$ & $\begin{array}{c}9.780^{* * *} \\
(3.323)\end{array}$ & $\begin{array}{l}9.108 \\
(9.313)\end{array}$ & $\begin{array}{l}9.78 \\
(9.148)\end{array}$ \\
\hline Horizontal & & $\begin{array}{c}0.318^{* *} \\
(0.151)\end{array}$ & & $\begin{array}{l}0.318 \\
(0.339)\end{array}$ \\
\hline Intercept & $\begin{array}{r}3.857^{* * *} \\
(0.047)\end{array}$ & $\begin{array}{r}3.813^{* * *} \\
(0.052)\end{array}$ & $\begin{array}{r}3.857^{* * *} \\
(0.115)\end{array}$ & $\begin{array}{c}3.813^{* * *} \\
(0.112)\end{array}$ \\
\hline No. of obs. & 117,039 & 117,039 & 117,039 & 117,039 \\
\hline Adjusted R-squared & 0.13 & 0.13 & 0.13 & 0.13 \\
\hline Year fixed effects & yes & yes & yes & yes \\
\hline Industry fixed effects & yes & yes & yes & yes \\
\hline Clustering of standard errors & no & no & yes & yes \\
\hline \multicolumn{5}{|l|}{ test V European $=\mathrm{V}$ American } \\
\hline F stat & 14.88 & 13.09 & 3.71 & 3.45 \\
\hline prob $>F$ stat & 0.00 & 0.00 & 0.00 & 0.06 \\
\hline \multicolumn{5}{|l|}{ test V European = V Asian } \\
\hline F stat & 10.85 & 11.86 & 1.46 & 1.66 \\
\hline prob $>F$ stat & 0.00 & 0.00 & 0.23 & 0.20 \\
\hline \multicolumn{5}{|l|}{ test V Asian = V American } \\
\hline F test & 0.32 & 0.66 & 0.04 & 0.09 \\
\hline prob $>$ F stat & 0.57 & 0.42 & 0.84 & 0.76 \\
\hline
\end{tabular}

Robust standard errors in parentheses * significant at $10 \%$; ${ }^{* *}$ significant at $5 \%$; ${ }^{* * *}$ significant at $1 \%$ 


\section{Appendix}

\section{Olley and Pakes Procedure}

We employ the semi-parametric estimation of the production function parameters suggested by Olley and Pakes (1996) and modified by Levinsohn and Petrin (2000) to account for the simultaneity bias. Productivity can be thought of as having two components, one that is random each period $\left(\eta_{\mathrm{it}}\right)$ and another that is known to the firm but unknown to the econometrician $\left(\omega_{i t}\right)$. Firms would thus adjust their inputs based on their anticipation or knowledge of the productivity component $\left(\omega_{i t}\right)$, introducing a simultaneity bias. The insight of the method is that the observable characteristics of the firm can be modeled as a monotonic function of the productivity of the firm. Inverting such a function allows the modeling of the unobserved component of the productivity as a function of the observed variables. While Olley and Pakes (1996) use investment to model the unobserved productivity shock we follow Levinsohn and Petrin (2000) approach and use raw materials as the instrument to correct for simultaneity bias (as was done by Hallward-Driemeier et al., 2001). We do so because of the lack of reliable information on investment expenditures.

To illustrate the insights of the method, we start with the following production function:

$v a_{i t}=y_{i t}-m_{i t}=\alpha+\beta_{l} * l_{i t}+\beta_{k} * k_{i t}+\omega_{i t}+\eta_{i t}$

where va stands for value added (i.e., output minus material inputs), 1 labor, $\mathrm{k}$ capital, and $\mathrm{i}$ and $\mathrm{t}$ are subscripts denoting firm and time, respectively. Capital is treated as a state variable while labor and materials are assumed to be freely variable inputs. $\eta_{\text {it }}$ represents the error term capturing unpredictable shocks, while $\omega_{i t}$ is a productivity shock which is unobserved by the econometrician but known to the firm. Firms adjust their variable inputs based on their anticipation or knowledge of the productivity component $\left(\omega_{i t}\right)$. Since there exists a correlation between the error term $\left(\omega_{\mathrm{it}}+\eta_{\mathrm{it}}\right)$ and the explanatory variables, a simple OLS procedure leads to inconsistent parameter estimates. 
As Levinsohn and Petrin (2003) showed, the unobserved productivity can be identified from the firms' observable variable input choices. The chosen variable input is material inputs. ${ }^{18}$ The demand for materials can be modeled as a monotonic function of the capital stock and the unobserved (to the econometrician) productivity shock.

$m_{i t}=f\left(k_{i t}, \omega_{i t}\right)$

The first advantage of using intermediate inputs is that they generally respond to the entire productivity term, while investment may respond only to the 'news' in the unobserved term. Further, intermediate inputs provide a simpler link between the estimation strategy and the economic theory, primarily because they are not typically state variables.

Assuming the function $f($.) is invertible, the unobservable productivity shock can be expressed as a function of observable variables

$\omega_{i t}=h\left(m_{i t}, k_{i t}\right)$

We assume that materials are a variable input whose choice is affected by $\omega_{i t}$ while capital is determined by past values of productivity only.

Substituting (3) into (2), we get the equation to be estimated in the first stage of the procedure:

$v a_{i t}=\alpha+\beta_{l} * l_{i t}+\beta_{k} * k_{i t}+h\left(m_{i t}, k_{i t}\right)+\eta_{i t}$

Note that the functional form of $h($.$) is not known. Therefore, \beta_{\mathrm{k}}$ cannot be obtained at this stage. We estimate equation (4) using a third order polynomial expansion in capital and materials to approximate the unknown form of $h($.$) . From this stage we obtain the consistent estimate of the$ labor input coefficient as well as the estimate of the third order polynomial in $m_{i t}$ and $k_{i t}$, to which we refer as $\psi_{\text {it }}$

\footnotetext{
${ }^{18}$ While Olley and Pakes (1996) use investment to model the unobserved productivity shock, we follow Levinsohn and Petrin (2000) approach and use materials as the instrument to correct for simultaneity bias (as was done by Hallward-Driemeier et al., 2001). We do so because of the lack of reliable information on investment expenditures.
} 
$\psi_{\mathrm{it}}=\beta_{k} * k_{i t}+h\left(m_{i t}, k_{i t}\right)(5)$

Thus, $h\left(m_{i t}, k_{i t}\right)=\psi_{\mathrm{it}}-\beta_{k} * k_{i t}(6)$

We proceed with the second stage where we estimate the effect of capital on output. Let's consider the expectation of $v a_{t+1}-\beta_{1} * l_{t+1}$ conditional on the information at time $t$. Assuming that $\omega_{\mathrm{it}}$ follows a first order Markov process, one can rewrite $\omega_{\mathrm{it}+1}$ as a function of $\omega_{\mathrm{it}}$, letting $\xi_{\mathrm{it}+1}$ be the innovation in $\omega_{i t+1}$. And $\omega_{i t}$ can be replaced with a function of $\mathrm{h}\left(\mathrm{m}_{\mathrm{it}}, \mathrm{k}_{\mathrm{it}}\right)$. Therefore the equation to be estimated in the second stage becomes:

$v a_{i t+1}-\beta_{l} * l_{i t+1}=c+\beta_{k} * k_{i t+1}+g\left(h_{i t}().\right)+\xi_{i t+1}+\eta_{i t+1}$

Since the functional for of $\mathrm{g}($.$) is not known, we use once more the third order polynomial$ expansion (with all interactions). Since the capital in use in a given period is assumed to be known at the beginning of the period and $\xi_{\mathrm{it}+1}$ is mean independent of all variables known at the beginning of the period, $\xi_{i t+1}$ is mean independent of $k_{i t+1}$. The consistent coefficient $\beta_{k}$ can thus be obtained by running non linear least squares on equation (7).

In summary, following Olley and Pakes(1996) and Levinsohn and Petrin (2003) we use a semiparametric estimator to generate time-varying firm-specific measures of plant productivity that are consistent even in the presence of input shares being influenced by the private knowledge of firm's productivity. The above procedure is performed for each sector separately and the obtained measures of productivity are used in the estimation of equation (1). ${ }^{19}$

\footnotetext{
${ }^{19}$ Since the procedure described above calls for using lagged variables, we employ a longer panel 1996-2000 to obtain productivity estimates but in the subsequent analysis of spillovers the timeframe is restricted to years 19982000 .
} 
Table A1. Distribution of Firms With Foreign Capital By Industry

\begin{tabular}{|c|c|c|c|c|c|c|}
\hline $\begin{array}{c}\text { Industry } \\
\text { code }\end{array}$ & Industry & $\begin{array}{c}\text { Domestic } \\
\text { firms }\end{array}$ & $\begin{array}{c}\text { European } \\
\text { affiliates }\end{array}$ & $\begin{array}{c}\text { American } \\
\text { affiliates }\end{array}$ & $\begin{array}{c}\text { Asian } \\
\text { affiliates }\end{array}$ & $\begin{array}{c}\text { All } \\
\text { firms }\end{array}$ \\
\hline & & \multicolumn{5}{|c|}{ percentages } \\
\hline 1 & Vegetable production & 1.61 & 0.91 & 0.69 & 1.48 & 1.54 \\
\hline 2 & Breeding & 0.19 & 0.08 & 0.00 & 0.00 & 0.18 \\
\hline 6 & Fishing and aquaculture & 0.06 & 0.00 & 0.00 & 0.00 & 0.05 \\
\hline 8 & Extraction of petroleum (incl. auxiliary services) & 0.88 & 0.95 & 0.46 & 0.25 & 0.88 \\
\hline 9 & Extraction of natural gas (incl. auxiliary services) & 0.07 & 0.14 & 0.00 & 0.00 & 0.08 \\
\hline 13 & Extraction of building material ores & 1.47 & 0.43 & 0.46 & 0.00 & 1.35 \\
\hline 14 & Extraction of clay and sand & 0.10 & 0.14 & 0.00 & 0.00 & 0.10 \\
\hline 15 & Extraction and processing of chemical ores & 0.03 & 0.02 & 0.23 & 0.00 & 0.03 \\
\hline 16 & Extraction and processing of salt & 0.18 & 0.08 & 0.00 & 0.00 & 0.17 \\
\hline 18 & Meat production and processing & 1.34 & 1.09 & 2.07 & 1.48 & 1.33 \\
\hline 19 & Processing and preserving of fish and fish products & 0.06 & 0.02 & 0.00 & 0.25 & 0.06 \\
\hline 20 & Processing and preserving of fruits and vegetables & 0.30 & 0.45 & 0.46 & 0.25 & 0.31 \\
\hline 21 & Production of vegetable and animal oil and fat & 0.13 & 0.16 & 0.23 & 0.74 & 0.14 \\
\hline 22 & Production of milk products & 0.65 & 0.43 & 0.46 & 0.49 & 0.63 \\
\hline 23 & Production of milling and starch products & 1.00 & 1.07 & 0.69 & 0.49 & 1.00 \\
\hline 24 & Manufacture of fodder & 0.04 & 0.08 & 0.00 & 0.00 & 0.04 \\
\hline 25 & Processing of other food products & 4.51 & 4.88 & 4.38 & 7.14 & 4.56 \\
\hline 26 & Beverages & 0.73 & 1.01 & 1.38 & 1.48 & 0.77 \\
\hline 28 & Textile industry & 3.91 & 7.31 & 4.84 & 2.22 & 4.23 \\
\hline 29 & Apparel & 0.18 & 0.29 & 0.00 & 0.00 & 0.19 \\
\hline 30 & Manufacture of leather and fur clothes & 0.07 & 0.04 & 0.23 & 0.00 & 0.07 \\
\hline 31 & Footwear and other leather goods & 0.84 & 2.86 & 0.23 & 0.99 & 1.03 \\
\hline 32 & Wood processing (excluding furniture) & 2.60 & 4.08 & 1.61 & 2.46 & 2.73 \\
\hline 33 & Pulp, paper and cardboard; related items & 0.30 & 0.84 & 0.23 & 0.49 & 0.35 \\
\hline 34 & Publishing, printing, reproduction of recorded media & 2.02 & 2.76 & 2.07 & 0.25 & 2.08 \\
\hline 36 & Crude oil processing & 0.02 & 0.06 & 0.23 & 0.00 & 0.02 \\
\hline 38 & Basic chemical products & 0.16 & 0.49 & 0.00 & 0.00 & 0.19 \\
\hline 40 & Dyes and varnishes & 0.13 & 0.27 & 0.00 & 0.00 & 0.14 \\
\hline 41 & Medicines and pharmaceutical products & 0.20 & 0.21 & 0.00 & 0.74 & 0.20 \\
\hline 42 & Soaps, detergents, cosmetics, perfumery & 0.12 & 0.37 & 0.69 & 0.99 & 0.15 \\
\hline 43 & Other chemical products & 0.14 & 0.10 & 0.46 & 0.00 & 0.13 \\
\hline 44 & Synthetic and man made fibers & 0.01 & 0.02 & 0.00 & 0.00 & 0.01 \\
\hline 45 & Rubber processing & 0.25 & 0.25 & 0.46 & 0.74 & 0.25 \\
\hline 46 & Plastic processing & 0.60 & 1.50 & 1.84 & 2.22 & 0.71 \\
\hline 47 & Glass and glassware & 0.24 & 0.37 & 0.46 & 0.00 & 0.26 \\
\hline 48 & Processing of ceramics (excl. building items) & 0.13 & 0.25 & 0.00 & 0.00 & 0.14 \\
\hline 49 & Ceramic boards and flags & 0.02 & 0.00 & 0.00 & 0.00 & 0.02 \\
\hline 50 & Brick, tile and other building material processing & 0.20 & 0.25 & 0.00 & 0.25 & 0.20 \\
\hline 51 & Cement, lime and plaster & 0.02 & 0.04 & 0.00 & 0.00 & 0.03 \\
\hline 52 & Processing of concrete, cement and lime items & 0.22 & 0.27 & 0.00 & 0.00 & 0.22 \\
\hline 53 & Cutting, shaping and finishing of stone & 0.11 & 0.10 & 0.00 & 0.00 & 0.11 \\
\hline 54 & Other non-metallic mineral products & 0.03 & 0.14 & 0.00 & 0.00 & 0.04 \\
\hline 55 & Metallurgy and ferroalloys processing & 0.03 & 0.12 & 0.23 & 0.00 & 0.04 \\
\hline 56 & Manufacture of tubes & 0.02 & 0.06 & 0.00 & 0.00 & 0.02 \\
\hline 57 & Other metallurgy products & 0.02 & 0.06 & 0.00 & 0.00 & 0.02 \\
\hline
\end{tabular}




\begin{tabular}{|c|c|c|c|c|c|c|}
\hline 58 & Precious metals and other non-ferrous metals & 0.04 & 0.19 & 0.00 & 0.00 & 0.06 \\
\hline 59 & Foundry & 0.14 & 0.14 & 0.46 & 0.00 & 0.15 \\
\hline 60 & Metal structures and products & 2.23 & 2.33 & 1.15 & 0.49 & 2.22 \\
\hline 61 & $\begin{array}{l}\text { Manufacture of equipment for producing and using } \\
\text { of mechanical power }\end{array}$ & 0.09 & 0.14 & 0.69 & 0.00 & 0.10 \\
\hline 62 & Machinery for general use & 0.17 & 0.33 & 0.23 & 0.25 & 0.19 \\
\hline 63 & Agricultural and forestry machinery & 0.05 & 0.12 & 0.00 & 0.25 & 0.06 \\
\hline 64 & Machine tools & 0.09 & 0.25 & 0.23 & 0.00 & 0.10 \\
\hline 65 & Other machines for special use & 0.15 & 0.37 & 0.46 & 0.00 & 0.17 \\
\hline 67 & Labor-saving devices and domestic machinery & 0.08 & 0.19 & 0.23 & 0.00 & 0.09 \\
\hline 68 & Computers and office means & 0.21 & 0.45 & 1.61 & 0.99 & 0.25 \\
\hline 69 & Electric machinery and appliances & 0.31 & 0.70 & 0.23 & 0.25 & 0.35 \\
\hline 70 & Radio, TV and communication equipment & 0.12 & 0.41 & 0.92 & 0.74 & 0.16 \\
\hline 71 & Medical, precision, optical instruments and apparatus & 0.24 & 0.45 & 0.69 & 0.00 & 0.26 \\
\hline 72 & Means of road transport & 0.20 & 0.29 & 0.23 & 0.25 & 0.21 \\
\hline 73 & Naval engineering and repair & 0.15 & 0.12 & 0.00 & 0.25 & 0.15 \\
\hline 74 & Production and repair of railway transport means & 0.04 & 0.02 & 0.00 & 0.00 & 0.03 \\
\hline 77 & Furniture & 1.22 & 1.89 & 1.61 & 0.99 & 1.28 \\
\hline 78 & Other industrial activities & 0.42 & 0.78 & 0.23 & 0.25 & 0.45 \\
\hline 79 & Electric power production and distribution & 0.04 & 0.04 & 0.00 & 0.00 & 0.04 \\
\hline 80 & Gas production and distribution & 0.01 & 0.08 & 0.00 & 0.00 & 0.02 \\
\hline 81 & Production and distribution of thermal energy & 0.08 & 0.02 & 0.23 & 0.00 & 0.08 \\
\hline 82 & Water collection, treatment and distribution & 0.15 & 0.00 & 0.00 & 0.00 & 0.14 \\
\hline 83 & Construction & 9.24 & 3.50 & 2.53 & 1.97 & 8.57 \\
\hline 84 & Wholesale and retail & 40.21 & 31.47 & 34.33 & 50.49 & 39.40 \\
\hline 85 & Hotels & 0.70 & 0.64 & 0.92 & 0.25 & 0.69 \\
\hline 86 & Restaurants & 4.45 & 1.94 & 3.23 & 5.17 & 4.20 \\
\hline 87 & Railway transport & 0.02 & 0.10 & 0.00 & & 0.03 \\
\hline 88 & Road transport & 3.18 & 4.76 & 2.07 & 3.20 & 3.32 \\
\hline 90 & Water transport & 0.06 & 0.10 & 0.00 & 0.25 & 0.07 \\
\hline 91 & Air transport & 0.02 & 0.02 & 0.00 & 0.00 & 0.02 \\
\hline 92 & Auxiliary transport activities and travel agencies & 0.25 & 0.39 & 0.00 & 1.72 & 0.27 \\
\hline 93 & Tourism agencies and assistance & 0.60 & 1.01 & 0.92 & 0.74 & 0.64 \\
\hline 95 & Telecommunication & 0.47 & 0.56 & 3.00 & 0.00 & 0.50 \\
\hline 97 & Real estate activities & 0.47 & 0.60 & 0.92 & 0.25 & 0.48 \\
\hline 98 & Computer and related activities & 0.82 & 2.00 & 4.61 & 0.49 & 0.97 \\
\hline 99 & Research and development & 0.17 & 0.12 & 0.46 & 0.00 & 0.17 \\
\hline 100 & Architecture, engineering and other technical services & 1.19 & 1.01 & 2.07 & 0.25 & 1.17 \\
\hline 101 & Other business activities & 2.51 & 3.58 & 6.45 & 2.22 & 2.65 \\
\hline 102 & Public administration and defense, compulsory social assistance & 0.03 & 0.00 & 0.00 & 0.00 & 0.03 \\
\hline 103 & Education & 0.31 & 0.14 & 0.23 & 0.00 & 0.29 \\
\hline 104 & Health and social work & 0.45 & 0.49 & 0.92 & 0.99 & 0.46 \\
\hline \multirow[t]{2}{*}{105} & Other services (collective, social and personal services) & 2.66 & 3.15 & 3.00 & 1.97 & 2.70 \\
\hline & TOTAL & 100 & 100 & 100 & 100 & 100 \\
\hline
\end{tabular}

